\title{
Combined Effects of Temperature and Nutrient Enrichment on Palatability of the Brown Alga Sargassum yezoense (Yamada) Yoshida \& T. Konno
}

\author{
Hikaru Endo, Kentaro Suehiro, Junji Kinoshita, Yukio Agatsuma \\ Graduate School of Agricultural Science, Tohoku University, Sendai, Japan \\ Email: h-endo@bios.tohoku.ac.jp
}

Received 11 January 2015; accepted 26 January 2015; published 30 January 2015

Copyright (C) 2015 by authors and Scientific Research Publishing Inc.

This work is licensed under the Creative Commons Attribution International License (CC BY). http://creativecommons.org/licenses/by/4.0/

\section{c) (i) Open Access}

\begin{abstract}
Global warming is predicted to strengthen marine plant-herbivore interactions. However, little is known about the effect of temperature on palatability and the associated chemical composition of marine macroalgae. To study the effects of physiological stress caused by the warm water temperatures and nutrient-poor conditions that occur during summer, we cultured the brown alga Sargassum yezoense at three different temperatures $\left(16^{\circ} \mathrm{C}, 22^{\circ} \mathrm{C}\right.$, and $\left.28^{\circ} \mathrm{C}\right)$ in both nutrient-enriched and non-enriched media. We then compared phlorotannin (i.e., defensive compounds) and nitrogen concentrations of $S$. yezoense as well as consumption rate by the sea urchin Hemicetrotus pulcherrimus among the treatment groups. No effect of culture temperature on phlorotannin and nitrogen concentrations or consumption rate was detected. Nutrient enrichment resulted in decreased phlorotannin concentration and increased nitrogen concentration. Although nutrient enrichment did not affect consumption rate, a positive correlation between nitrogen concentration and consumption rate was detected. In contrast, there was no correlation between phlorotannin concentration and consumption rate. These results suggested that palatability of $S$. yezoense to $H$. pulcherrimus might not be affected by elevated temperature but that it could increase with nutrient enrichment.
\end{abstract}

\section{Keywords}

Climate Change, Plant-Herbivore Interaction, Defensive Compound, Marine Macroalgae, Sea Urchin Grazing 


\section{Introduction}

Global warming is predicted to change plant-herbivore interactions in terrestrial environments. This prediction is based on observations of an increased consumption rate by insect herbivores and decreased concentrations of certain defensive compounds, such as nonstructural carbohydrates and phenolics, in plants grown at elevated temperature [1] [2]. Plant-herbivore interactions in marine environments are often stronger than those in terrestrial setting [3] [4], and they also are predicted to be strengthened by global warming [5]-[7]. For example, O’Connor [5] and Poore et al. [6] showed that elevated temperature increased the consumption rate of the brown algae Sargassum spp. by herbivorous amphipods. Burnell et al. [7] reported that increased grazing on a seagrass species by a sea urchin caused by elevated temperature and ocean acidification was ameliorated by nutrient enrichment. However, it is unclear whether consumption rate of macroalgae by herbivores or palatability of the algae is affected by elevated temperature. Little is known about the combined effects of temperature and nutrient enrichment on palatability and the associated chemical composition of marine macroalgae, whereas increased rate of consumption by herbivores can be explained by the increased metabolic rate induced by elevated temperature [5].

Large brown algae that belong to the orders Laminariales (kelp) and Fucales (fucoid), including Sargassum spp., are the dominant taxa present on intertidal and subtidal rocky shores in temperate and subarctic regions of the world [8] [9]. These algae frequently experience intensive grazing by herbivorous animals such as sea urchins, molluscs, and fishes [10]. Brown algae contain unique compounds called phlorotannins, which are known to have secondary roles as chemical defenses (e.g., herbivore deterrents, digestion inhibitors, antibacterial agents, and UV screens) and primary roles in constructing and strengthening the cell walls [11]. The concentrations of phlorotannins are known to be affected by abiotic and biotic factors such as nutrient availability, UV-B radiation, and grazing [11], but little is known about the effect of temperature [6] [12]. Nitrogen concentration is another important factor that affects the palatability of brown algae [13]. Nutrient enrichment is known to result in increased palatability [14], decreased phlorotannin concentration [11], and increased nitrogen concentration [15]. However, it is unclear whether decreased phlorotannin concentration or increased nitrogen concentration is responsible for increased palatability caused by nutrient enrichment.

The large brown alga Sargassum yezoense is one of the dominant species on wave exposed rocky shores in northeastern Japan [16] [17]. This species creates patches by elongation of perennial prostrate stipes and produces annual shoots during summer [16]. It experiences high seawater temperature of $28^{\circ} \mathrm{C}$ and grazing by the sea urchins Hemicentrotus pulcherrimus and Mesocentrotus nudus between summer and autumn along the coast of the Oshika Peninsula (unpublished data), near the southern limit of its distributional range [18]. This high temperature may affect the palatability of this alga to herbivores.

To test this hypothesis, we conducted a culture experiment to evaluate the combined effects of temperature and nutrient enrichment on phlorotannnin and nitrogen concentrations, and palatability of S. yesoense. Because $S$. yezoense experiences temperatures ranging from $16^{\circ} \mathrm{C}$ to $28^{\circ} \mathrm{C}$ between July and September (unpublished data), excised shoots from this species were cultured at $16^{\circ} \mathrm{C}, 22^{\circ} \mathrm{C}, 28^{\circ} \mathrm{C}$ in both nutrient-enriched and non-enriched media. As an indicator of palatability, consumption rate of $S$. yezoense by the sea urchin $H$. pulcherrimus was measured under a fixed temperature of $22^{\circ} \mathrm{C}$ to remove the temperature effect on grazing activity of the sea urchin. We addressed the following questions: 1) Do temperature and nutrient enrichment have significant effects on phlorotannin and nitrogen concentrations and palatability? 2) Are there significant correlations between the rate of consumption by the sea urchin and phlorotannin or nitrogen concentration of $S$. yezoense?

\section{Materials and Methods}

\subsection{Culture Experiment}

S. yezoense specimens with several short shoots were collected in September 2013 from six different patches at 2 - 3 m depth along the Kitsune-zaki coast (3951'20"N, 139 48'56"E), which is located on the Oshika Peninsula, Miyagi Prefecture, northeastern Japan. The specimens were assumed to be derived from six different individuals because this species creates patches by elongation of perennial prostrate stipes. $H$. pulcherrimus specimens with test diameter of ca. $30 \mathrm{~mm}$ were also collected. These specimens were transported to our laboratory in insulated cool boxes. For Sargassum specimens, 36 apical shoots without vesicles were excised from each of the 6 specimens, for a total of 216 shoots, and groups of 6 shoots were placed in 36 flasks $(2 \mathrm{~L})$ containing filtered seawater. These flasks were maintained with aeration in incubators at the temperature recorded at the time of col- 
lection $\left(23.4^{\circ} \mathrm{C}\right)$ for ca. $24 \mathrm{~h}$ to reduce the negative effects of excision. Light was provided by eight $40 \mathrm{~W}$ cool white fluorescent tubes in the incubators. Photon flux density was set at $70 \mu \mathrm{mol}$ photons $/ \mathrm{m}^{2} / \mathrm{s}$. Photoperiod was set at $12 \mathrm{~h} \mathrm{~L}$ (light):12 h D (dark).

Thirty-six sea urchin specimens were maintained in a $60 \mathrm{~L}$ tank with aeration at $23^{\circ} \mathrm{C}$ for 9 days. The brown alga Undaria pinnatifida was fed to the sea urchins once every 2 days to avoid overestimation of consumption rate by the sea urchins when starved [19]. Seawater was changed once every 2 days. Photon flux density was set at $70 \mu \mathrm{mol}$ photons $/ \mathrm{m}^{2} / \mathrm{s}$, and photoperiod was set at $12 \mathrm{~h} \mathrm{~L}$ (light): $12 \mathrm{~h} \mathrm{D}$ (dark).

To evaluate the combined effects of temperature and nutrient enrichment on phlorotannin and nitrogen concentrations and consumption rate by the sea urchin, flasks containing six shoots were cultured at $16^{\circ} \mathrm{C}, 22^{\circ} \mathrm{C}$, $28^{\circ} \mathrm{C}$ in both nutrient-enriched (25\% PESI) [20] and non-enriched media made from filtered seawater (i.e., a total of six treatments) for 8 days. Each treatment was replicated using the six flasks containing shoots derived from six different patches, as physiological responses might differ among individuals [21]. These shoots were maintained at a photon flux density of $180 \mu \mathrm{mol}$ photons $/ \mathrm{m}^{2} / \mathrm{s}$, which is the saturation light level for photosynthesis of some Japanese Sargassum spp. [22], and a photoperiod of the $12 \mathrm{~h} \mathrm{L:12} \mathrm{h} \mathrm{D.} \mathrm{The} \mathrm{culture} \mathrm{medium} \mathrm{in}$ each flask was changed every 2 days. The concentrations of ammonia, nitrate, nitrite, and phosphate in both nutrient-enriched and non-enriched medium were measured five times at the start of the experiment using an autoanalyzer (QuAAtro 2-HR; BLTEC, Japan). After the 8 days culture period, two of six shoots cultured in each flask were removed to measure phlorotannin and nitrogen concentrations, and the remaining four shoots were used to measure consumption rate of $S$. yezoense by the sea urchins.

\subsection{Measurement of Phlorotannin Concentration}

One of two shoots taken from each flask was used to measure phlorotannin concentration. A $0.2 \mathrm{~g}$ aliquot of tissue was cut from each shoot and immediately placed in a $15 \mathrm{~mL}$ conical tube containing $4 \mathrm{~mL}$ of $80 \%$ aqueous methanol at $4^{\circ} \mathrm{C}$ in the dark for 10 days. The phlorotannin concentration of each sample was measured using the Folin-Ciocalteu method according to Kamiya et al. [23]. Each sample was incubated for 10 days and then ground with $6 \mathrm{~mL}$ of $80 \%$ aqueous methanol using a mortar and pestle. This extract was centrifuged at $3500 \mathrm{rpm}$ at $4{ }^{\circ} \mathrm{C}$ for $15 \mathrm{~min}$, and the volume of the supernatant was measured (with $0.05 \mathrm{ml}$ accuracy). One milliliter of the extract was placed in a microtube and centrifuged at $14,000 \mathrm{rpm}$ at $4^{\circ} \mathrm{C}$ for $5 \mathrm{~min}$. Next, $50 \mu \mathrm{L}$ from each extract or $80 \%$ aqueous methanol as a reference were added to $1 \mathrm{~mL}$ of distilled water and $1 \mathrm{~mL}$ of $40 \%$ Folin-Ciocalteu reagent (F9252, Sigma-Aldrich, St Louis, MO, USA) in an $8 \mathrm{~mL}$ glass tube. After 5 min incubation at room temperature, $1 \mathrm{~mL}$ of $2 \mathrm{~N} \mathrm{Na}_{2} \mathrm{CO}_{3}$ was added, followed by incubation in a $50^{\circ} \mathrm{C}$ water bath for $30 \mathrm{~min}$. The absorbance of each solution and anhydrous phloroglucinol (1,3,5-trihydroxybenzene, 322 - 56,502, Wako, Osaka, Japan) as the standard were measured at $765 \mathrm{~nm}$ using a spectrophotometer (UV-1800, Shimadzu, Kyoto, Japan). The phlorotannin concentrations are expressed as a percentage of the dry weight.

\subsection{Measurement of Nitrogen Concentration}

Another shoot taken from each flask was used to measure nitrogen concentration. Each shoot was placed in a screw vial and dried in a convection oven at $80^{\circ} \mathrm{C}$ for $72 \mathrm{~h}$. After crushing and weighing each dry sample, nitrogen concentration was measured using an Organic Elemental Analyzer (FLASH2000, Thermo Scientific, USA).

\subsection{Measurement of Consumption Rate of $S$, yezoense by $H$. pulcherrimus}

The remaining four shoots in each flask were used to measure the sea urchin's rate of consumption. Wet weights of the shoots (initial wet weight) were measured using an electrical balance ( $0.1 \mathrm{mg}$ accuracy) after removal of excess moisture by blotting on paper towels. These four shoots and one sea urchin were placed in a $2 \mathrm{~L}$ flask containing filtered seawater, and the flasks were maintained in incubators with aeration at $22^{\circ} \mathrm{C}$ for $24 \mathrm{~h}$. Photon flux density was set at $70 \mu \mathrm{mol}$ photons $/ \mathrm{m}^{2} / \mathrm{s}$, and the photoperiod was set at $12 \mathrm{~h} \mathrm{L:12} \mathrm{h} \mathrm{D.} \mathrm{After} 24 \mathrm{~h}$, wet weights of the shoots (final wet weight) were measured. Consumption rate was calculated as initial wet weight -final wet weight of the four shoots, after initial wet weights were corrected based on the percentage change of wet weight of another 12 shoots maintained for $24 \mathrm{~h}$ in the same conditions without the sea urchin.

\subsection{Statistical Analysis}

The combined effects of temperature and nutrient enrichment on phlorotannin and nitrogen concentrations and 
consumption rate of $S$. yezoense by the sea urchin were analyzed by two-way analysis of variance (ANOVA) after logarithmic transformation because some data were not normally distributed (Shapiro-Wilk test, $\mathrm{P}<0.05$ ) and did not show homogeneous variances (Levene test, $\mathrm{P}<0.05$ ). Correlations between phlorotannin or nitrogen concentration and consumption rate by $H$. pulcherrimus were analyzed using the Pearson's test. These analyses were performed using SPSS Statistics 20.0 (IBM, Armonk, NY, USA).

\section{Results}

The concentrations of ammonia, nitrate, nitrite, and phosphate in the nutrient-enriched medium were $0.117 \pm$ 0.005 , $2.924 \pm 0.109,0.024 \pm 0.001$, and $0.118 \pm 0.007 \mathrm{mg} / \mathrm{L}$, respectively, and those in the non-enriched medium were $<0.005,0.068 \pm 0.010,0.023 \pm 0.002$, and $0.014 \pm 0.001 \mathrm{mg} / \mathrm{L}$, respectively.

Figure 1 shows the phlorotannin and nitrogen concentrations and the consumption rate of S. yezoense cultured in the six treatments. Results of two-way ANOVA showed no significant effect of temperature on phlorotannin and nitrogen concentrations. However, there were significant effects of nutrient enrichment on phlorotannin and nitrogen concentrations (Table 1). Phlorotannin concentrations of the shoots cultured in the enriched medium were lower than those of the shoots cultured in the non-enriched medium. In contrast, nitrogen concentrations of the shoots cultured in the enriched medium were higher than those of the shoots cultured in the nonenriched medium. Significant effects of temperature and nutrient enrichment on consumption rate by the sea urchin were not detected. Although the mean rate of consumption of the shoots cultured in the enriched medium at $22^{\circ} \mathrm{C}$ tended to be higher than that of the shoots cultured in the non-enriched medium at $22^{\circ} \mathrm{C}$, the standard deviation was relatively large in the former treatment.

Figure 2 shows the relationships between phlorotannin or nitrogen concentrations and consumption rate of $S$. yezoense cultured in the six treatments. As there was no significant effect of temperature and nutrient enrichment on consumption rate by the sea urchins, data from all treatments were pooled in this analysis. There was no significant correlation between phlorotannin concentration and consumption rate by the sea urchins. In contrast, a significant positive correlation between nitrogen concentration and consumption rate was detected.
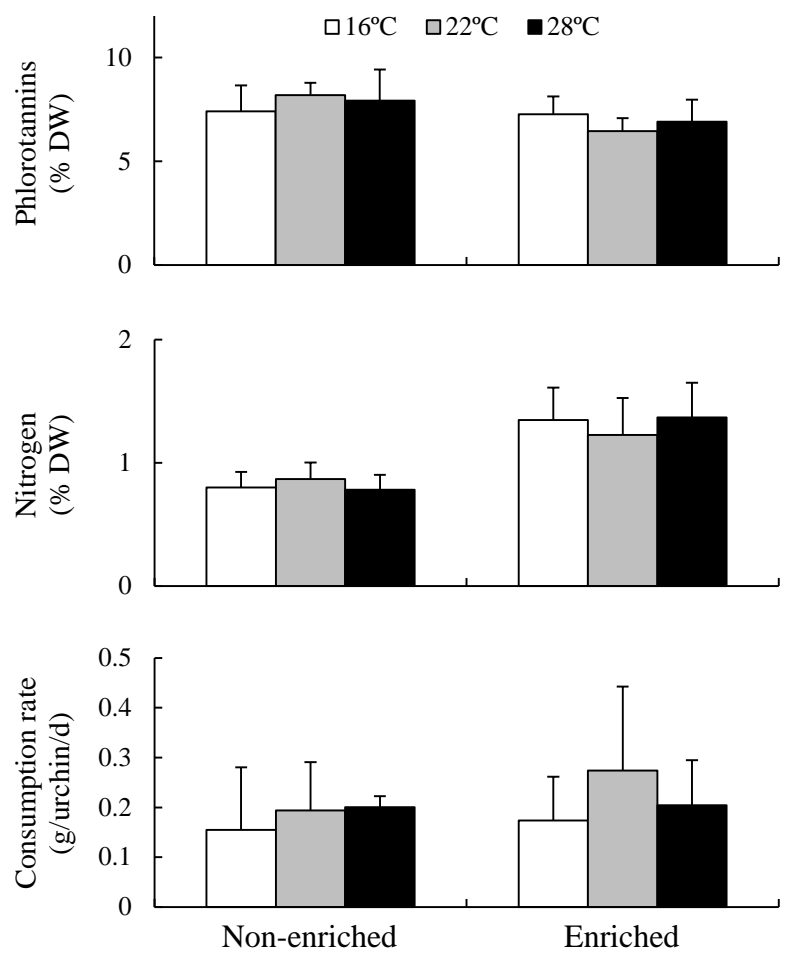

Figure 1. The phlorotannin and nitrogen concentrations and the consumption rate of $S$. yezoense cultured in the six treatments. Mean $\pm \mathrm{SD} ; \mathrm{n}=6$ flasks. 

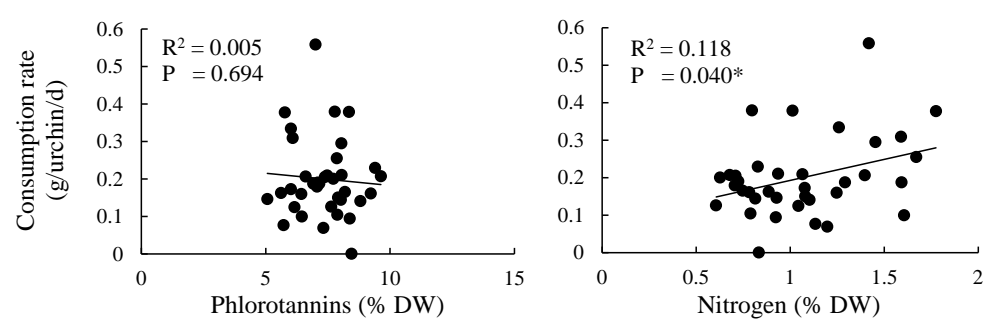

Figure 2. The relationships between phlorotannin or nitrogen concentrations and consumption rate of $S$. yezoense. Data from the six treatments were pooled in these graphs.

Table 1. Results of ANOVA on the effect of temperature and nutrient enrichment on the phlorotannin and nitrogen concentrations, and consumption rate by the sea urchin $H$. pulcherrimus in S. yezoense.

\begin{tabular}{ccccc}
\hline Source & df & MS & F & P \\
\hline Phlorotannin concentration & & & & 0.971 \\
Temperature & 2 & 0.031 & 0.029 & $0.009^{*}$ \\
Nutrient & 1 & 8.370 & 7.865 & 0.174 \\
Temperature $\times$ Nutrient & 2 & 1.975 & 1.856 & 0.946 \\
Nitrogen concentration & & & $<0.001$ \\
Temperature & 2 & 0.003 & 0.055 & 0.400 \\
Nutrient & 1 & 2.231 & 46.530 & 0.945 \\
Temperature $\times$ Nutrient & 2 & 0.045 & & 0.300 \\
Consumption rate & & & 1.254 & 0.346 \\
Temperature & 2 & 0.016 & 0.915 & 0.665 \\
Nutrient & 1 & 0.012 & 0.414 & \\
Temperature $\times$ Nutrient & 2 & 0.005 & & \\
\hline
\end{tabular}

${ }^{*} \mathrm{P}<0.05$.

\section{Discussion}

In the present study we found no significant effect of temperature within the range of $16^{\circ} \mathrm{C}$ to $28^{\circ} \mathrm{C}$ on phlorotannin and nitrogen concentrations and consumption rate of $S$. yezoense by the sea urchin $H$. pulcherrimus in an 8 days experiment, which suggests that the effect of temperature on palatability of this species was too small to detect, at least in short-term experiments. In contrast, we found that nutrient enrichment resulted in decreased phlorotannin concentration and increased nitrogen concentration of $S$. yezoense. Although a significant effect of nutrient enrichment on the consumption rate of $S$. yezoense by the sea urchin was not detected, we did found a significant positive correlation between nitrogen concentration and consumption rate by the sea urchin. These results indicate that palatability of this species can increase with increasing nitrogen concentration as a result of nutrient enrichment.

Poore et al. [6] also found no effect of elevation of temperature from $23^{\circ} \mathrm{C}$ to $26^{\circ} \mathrm{C}$ on the phlorotannin and nitrogen concentrations of Sargassum linearifolium in their 14 days experiment. Hay et al. [12] showed that an increase of temperature from $21^{\circ} \mathrm{C}$ to $28^{\circ} \mathrm{C}$ did not affect phlorotannin concentration but decreased nitrogen concentration of Sargassum flavicans in an 8 days experiment. We previously reported that a wider range of temperature from $10^{\circ} \mathrm{C}$ to $30^{\circ} \mathrm{C}$ had no effect on the phlorotannin concentration of Sargassum patens in a 9 days experiment [24]. Thus, increasing evidence suggests that effects of temperature on phlorotannin concentration of Sargassum spp. cannot be detected in short-term experiment, although the effects on nitrogen concentration are inconsistent. 
O’Connor [5] reported that an increase in temperature from $23^{\circ} \mathrm{C}$ to $29^{\circ} \mathrm{C}$ increased the consumption rate of Sargassum filipendula by the amphipod Ampithoe longimana. Poore et al. [6] also reported that a temperature increase from $23^{\circ} \mathrm{C}$ to $26^{\circ} \mathrm{C}$ increased the consumption rate of $S$. linearifolium by the amphipod Peraphithoe parmerong. In the present study, consumption rates of $S$. yezoense by the sea urchin $H$. pulcherrimus cultured at three different temperatures did not differ significantly, and this result coincides with the lack of effect of temperature on phlorotannin and nitrogen concentrations of the algae. These results suggest that the effect of temperature on palatability of Sargassum spp. is less important than the temperature effect on grazing activity of herbivores. However, nutrient enrichment also had no effect on consumption rate. These results may mean that the replication design (six times) was too small to estimate accurately the sea urchin's consumption rate, as the values exhibited a large standard deviation in some treatments (e.g., the nutrient enriched treatment at $22^{\circ} \mathrm{C}$ ). In addition, Sargassum spp. contains many secondary metabolites that may act as herbivore deterrents [25]. Further studies of the temperature effect on palatability and the associated chemical composition of Sargassum spp. are needed to make conclusions about the warming effects on Sargassum-herbivore interactions.

In the present study, nutrient enrichment resulted in decreased phlorotannin concentration in $S$. yezoense, as has been reported for many other species of brown algae [11]. Arnold and Targett [26] proposed that the phlorotannin concentration decrease when the growth rate is high but increase when the growth rate is low, at which times rates of phlorotannin synthesis outpace rates of decomposition and incorporation of phlorotannins into cell walls [11] [26]. Nutrient enrichment generally enhances growth of brown algae [15] [27], which explains the decreased phlorotannin concentration in $S$. yezoense cultured in the nutrient-rich treatments. Although phlorotannins are known to act as herbivore deterrents depending on their concentration [11], there was no significant correlation between phlorotannin concentration and consumption rate of $S$. yezoense by $H$. pulcherrimus in the present study. This suggests that the phlorotannin concentration of $5 \%-10 \%$ in S. yezoense is not enough to deter feeding by $H$. pulcherrimus. Steinberg et al. [28] reported that feeding by the sea urchin Evechinus chloroticus was deterred by food with a phlorotannin concentration of $13.4 \%$ but not of $5.0 \%$. In contrast, we detected a significant positive correlation between nitrogen concentration and consumption rate of $S$. yezoense by $H$. pulcherrimus. Thus, increased nitrogen concentration seems to have greater importance than decreased phlorotannin concentration in determining the palatability of $S$. yezoense to $H$. pulcherrimus. Macroalgae store nitrogen in organic forms, including amino acids [29] [30], or inorganic ions [31], and the amino acid L-phenylalanine is known to be a feeding stimulant for sea urchin species [32]. Therefore, nutrient enrichment might stimulate feeding by $H$. pulcherrimus due to increased nitrogen concentration of the algae, but this hypothesis needs to be tested.

In recent years, brown algae beds of the world have been experiencing regional decline under elevated seawater temperature [33]-[35]. Nutrient enrichment is used to restore the kelp beds in Japan [36], because it has been shown to enhance recruitment and survival of the algae [15] [37] [38]. However, results of the present study suggest the possibility that nutrient enrichment may increase the palatability of Sargassum by increasing its nitrogen concentration. Therefore, nutrient enrichment combined with herbivore exclusion seems to be the best way to enhance recruitment and survival of brown algal species. Further studies of the combined effects of temperature and environmental factors, including nutrient enrichment, on palatability of other species are needed to predict the effects of global warming and to propose ways to restore macroalgae beds in the warming world.

\section{Acknowledgements}

We thank Prof. M. Kamiya of Fukui Prefectural University and Dr. K. Ito of Tohoku University for illustrating the determination methods of phlorotannin and nitrogen concentration, respectively. We also thank Dr. R. Sasaki and Mr. H. Hiratsuka of Miyagi Fisheries Cooperative for their help in collection of seawater and samples, respectively. This work was supported by the project "Tohoku Ecosystem-Associated Marine Sciences (TEAMS)”.

\section{References}

[1] Zvereva, E.L. and Kozlov, M.V. (2006) Consequences of Simultaneous Elevation of Carbon Dioxide and Temperature for Plant-Herbivore Interactions: A Metaanalysis. Global Change Biology, 12, 27-41. http://dx.doi.org/10.1111/j.1365-2486.2005.01086.x

[2] Bidart-Bouzat, M.G. and Imeh-Nathaniel, A. (2008) Global Change Effects on Plant Chemical Defenses against Insect 
Herbivores. Journal of Integrative Plant Biology, 50, 1339-1354. http://dx.doi.org/10.1111/j.1744-7909.2008.00751.x

[3] Cyr, H. and Face, M.L. (1993) Magnitude and Patterns of Herbivory in Aquatic and Terrestrial Ecosystems. Nature, 361, 148-150. http://dx.doi.org/10.1038/361148a0

[4] Burkepile, D.E. (2013) Comparing Aquatic and Terrestrial Grazing Ecosystems: Is the Grass Really Greener? Oikos, 122, 306-312. http://dx.doi.org/10.1111/j.1600-0706.2012.20716.x

[5] O’Connor, M.I. (2009) Warming Strengthens an Herbivore-Plant Interaction. Ecology, 90, 388-398. http://dx.doi.org/10.1890/08-0034.1

[6] Poore, A.G., Graba-Landry, A., Favret, M., Brennand, H.S., Byrne, M. and Dworjanyn, S.A. (2013) Direct and Indirect Effects of Ocean Acidification and Warming on a Marine Plant-Herbivore Interaction. Oecologia, 173, 1113-1124. http://dx.doi.org/10.1007/s00442-013-2683-y

[7] Burnell, O.W., Russell, B.D., Irving, A.D. and Connell, S.D. (2013) Eutrophication Offsets Increased Sea Urchin Grazing on Seagrass Caused by Ocean Warming and Acidification. Marine Ecology Progress Series, 485, 37-46. http://dx.doi.org/10.3354/meps10323

[8] Schiel, D.R. and Foster, M.S. (1986) The Structure of Subtidal Algal Stands in Temperate Waters. Oceanography and Marine Biology Annual Review, 24, 265-307.

[9] Steneck, R.S., Graham, M.H., Bourque, B.J., Corbett, D., Erlandson, J.M., Estes, J.A. and Tegner, M.J. (2002) Kelp Forest Ecosystems: Biodiversity, Stability, Resilience and Future. Environmental Conservation, 29, 436-459. http://dx.doi.org/10.1017/S0376892902000322

[10] Poore, A.G., Campbell, A.H., Coleman, R.A., Edgar, G.J., Jormalainen, V., Reynolds, P.L., Sotka, E.E., Stachowicz, J.J., Taylor, R.B., Vanderklift M.A. and Duffy, J.E. (2012) Global Patterns in the Impact of Marine Herbivores on Benthic Primary Producers. Ecology Letters, 15, 912-922. http://dx.doi.org/10.1111/j.1461-0248.2012.01804.x

[11] Amsler, C.D. and Fairhead, V.A. (2005) Defensive and Sensory Chemical Ecology of Brown Algae. Advances in Botanical Research, 43, 1-91. http://dx.doi.org/10.1016/S0065-2296(05)43001-3

[12] Hay, K.B., Millers, K.A., Poore, A.G. and Lovelock, C.E. (2010) The Use of Near Infrared Reflectance Spectrometry for Characterization of Brown Algal Tissue. Journal of Phycology, 46, 937-946. http://dx.doi.org/10.1111/j.1529-8817.2010.00890.x

[13] Van Alstyne, K.L., Pelletreau, K.N. and Kirby, A. (2009) Nutritional Preferences Override Chemical Defenses in Determining Food Choice by a Generalist Herbivore, Littorina sitkana. Journal of Experimental Marine Biology and Ecology, 379, 85-91. http://dx.doi.org/10.1016/j.jembe.2009.08.002

[14] Chan, A.Y., Lubarsky, K., Judy, K.N. and Fong, P. (2012) Nutrient Addition Increases Consumption Rates of Tropical Algae with Different Initial Palatabilities. Marine Ecology Progress Series, 465, 25-31. http://dx.doi.org/10.3354/meps09946

[15] Gao, X., Endo, H., Taniguchi, K. and Agatsuma, Y. (2013) Combined Effects of Seawater Temperature and Nutrient Condition on Growth and Survival of Juvenile Sporophytes of the Kelp Undaria pinnatifida (Laminariales; Phaeophyta) Cultivated in Northern Honshu, Japan. Journal of Applied Phycology, 25, 269-275. http://dx.doi.org/10.1007/s10811-012-9861-x

[16] Agatsuma, Y., Narita, K. and Taniguchi, K. (2002) Annual Life Cycle and Productivity of the Brown Alga Sargassum yezoense off the Coast of the Oshika Peninsula, Japan. Aquaculture Science, 50, 25-30.

[17] Kinoshita, J., Endo, H. and Agatsuma, Y. (2013) Sexual Differences in Gonad Size and Color of Strongylocentrotusnudus and Hemicentrotus pulcherrimus (Echinoidea: Echinodermata), from Maturation to Post-Spawning in Sargassum yezoense Bed (Phaeophyceae: Heterokontophyta). Cahiers de Biologie Marine, 54, 633-639.

[18] Yoshida, T. (1998) Marine Algae of Japan. Uchida Roukakuho Publishing, Tokyo.

[19] Lawrence, J.M., Plank, L.R. and Lawrence, A.L. (2003) The Effect of Feeding Frequency on Consumption of Food, Absorption Efficiency, and Gonad Production in the Sea Urchin Lytechinus variegatus. Comparative Biochemistry and Physiology Part A: Molecular and Integrative Physiology, 134, 69-75. http://dx.doi.org/10.1016/S1095-6433(02)00222-2

[20] Tatewaki, M. (1966) Formation of a Crustaceous Sporophyte with Unilocular Sporangia in Scytosiphon lomentaria. Phycologia, 6, 62-66. http://dx.doi.org/10.2216/i0031-8884-6-1-62.1

[21] Jormalainen, V. and Ramsay, T. (2009) Resistance of the Brown Alga Fucus vesiculosus to Herbivory. Oikos, 118, 713-722. http://dx.doi.org/10.1111/j.1600-0706.2008.17178.x

[22] Gao, K. and Umezaki, I. (1988) Comparative Photosynthetic Capacities of the Leaves of Upper and Lower Parts of Sargassum Plants. Botanica Marina, 31, 231-236. http://dx.doi.org/10.1515/botm.1988.31.3.231

[23] Kamiya, M., Nishio, T., Yokoyama, A., Yatsuya, K., Nishigaki, T., Yoshikawa, S. and Ohki, K. (2010) Seasonal Variation of Phlorotannin in Sargassacean Species from the Coast of the Sea of Japan. Phycological Research, 58, 
53-61. http://dx.doi.org/10.1111/j.1440-1835.2009.00558.X

[24] Endo, H., Suehiro, K., Kinoshita, J., Gao, X. and Agatsuma, Y. (2013) Combined Effects of Temperature and Nutrient Availability on Growth and Phlorotannin Concentration of the Brown Alga Sargassum patens (Fucales; Phaeophyceae). American Journal of Plant Sciences, 4, 14-20. http://dx.doi.org/10.4236/ajps.2013.412A2002

[25] Liu, L., Heinrich, M., Myers, S. and Dworjanyn, S.A. (2012) Towards a Better Understanding of Medicinal Uses of the Brown Seaweed Sargassum in Traditional Chinese Medicine: A Phytochemical and Pharmacological Review. Journal of Ethnopharmacology, 142, 591-619. http://dx.doi.org/10.1016/j.jep.2012.05.046

[26] Arnold, T.M. and Targett, N.M. (2003) To Grow and Defend: Lack of Tradeoffs for Brown Algal Phlorotannins. Oikos, 100, 406-408. http://dx.doi.org/10.1034/j.1600-0706.2003.11680.x

[27] Schaffelke, B. and Klumpp, D.W. (1998) Nutrient-Limited Growth of the Coral Reef Macroalga Sargassum baccularia and Experimental Growth Enhancement by Nutrient Addition in Continuous Flow Culture. Marine Ecology Progress Series, 164, 199-211. http://dx.doi.org/10.3354/meps164199

[28] Steinberg, P.D., Estes, J.A. and Winter, F.C. (1995) Evolutionary Consequences of Food Chain Length in Kelp Forest Communities. Proceedings of the National Academy of Sciences of the United States of America, 92, 8145-8148. http://dx.doi.org/10.1073/pnas.92.18.8145

[29] Bird, K.T., Habig, C. and DeBusk, T. (1982) Nitrogen Allocation and Storage Patterns in Gracilaria tikvahiae (Rhodophyta). Journal of Phycology, 18, 344-348. http://dx.doi.org/10.1111/j.1529-8817.1982.tb03194.x

[30] Naldi, M. and Wheeler, P.A. (1999) Changes in Nitrogen Pools in Ulva fenestrata (Chlorophyta) and Gracilaria pacifica (Rhodophyta) under Nitrate and Ammonium Enrichment. Journal of Phycology, 35, 70-77.

http://dx.doi.org/10.1046/j.1529-8817.1999.3510070.x

[31] Chapman, A.R.O. and Craigie, J.S. (1977) Seasonal Growth in Laminaria longicruris: Relations with Dissolved Inorganic Nutrients and Internal Reserves of Nitrogen. Marine Biology, 40, 197-205. http://dx.doi.org/10.1007/BF00390875

[32] Klinger, T.S. and Lawrence, J.M. (1984) Phagostimulation of Lytechinus variegatus (Lamarck) (Echinodermata: Echinoidea). Marine and Freshwater Behaviour and Physiology, 11, 49-67. http://dx.doi.org/10.1080/10236248409387034

[33] Johnson, C.R., Banks, S.C., Barrett, N.S., Cazassus, F., Dunstan, P.K., Edgar, G.J., Frusher, S.D., Gardner, C., Haddon, M., Helidoniotis, F., Hill, K.L., Holbrook, N.J., Hosie, G.W., Last, P.R., Ling, S.D., Melbourne-Thomas, J., Miller, K., Pecl, G.T., Richardson, A.J., Ridgway, K.R., Rintoul, S.R., Ritz, D.A., Ross, D.J., Sanderson, J.C., Shepherd, S.A., Slotwinski, A., Swadling, K.M. and Taw, N. (2011) Climate Change Cascades: Shifts in Oceanography, Species’ Ranges and Subtidal Marine Community Dynamics in Eastern Tasmania. Journal of Experimental Marine Biology and Ecology, 400, 17-32. http://dx.doi.org/10.1016/j.jembe.2011.02.032

[34] Díez, I., Muguerza, N., Santolaria, A., Ganzedo, U. and Gorostiaga, J.M. (2012) Seaweed Assemblage Changes in the Eastern Cantabrian Sea and Their Potential Relationship to Climate Change. Estuarine, Coastal and Shelf Science, 99, 108-120. http://dx.doi.org/10.1016/j.ecss.2011.12.027

[35] Tanaka, K., Taino, S., Haraguchi, H., Prendergast, G. and Hiraoka, M. (2012) Warming off Southwestern Japan Linked to Distributional Shifts of Subtidal Canopy-Forming Seaweeds. Ecology and Evolution, 2, 2854-2865. http://dx.doi.org/10.1002/ece3.391

[36] Agatsuma, Y., Endo, H., Yoshida, S., Ikemori, C., Takeuchi, Y., Fujishima, H., Nakajima, K., Sano, M., Kanezaki, N., Imai, H., Yamamoto, N., Kanahama, H., Matsubara, T., Takahashi, S., Isogai, T. and Taniguchi, K. (2014) Enhancement of Saccharina Kelp Production by Nutrient Supply in the Sea of Japan off Southwestern Hokkaido, Japan. Journal of Applied Phycology, 26, 1845-1852. http://dx.doi.org/10.1007/s10811-013-0196-Z

[37] North, W.J. and Zimmerman, R.C. (1984) Influences of Macronutrients and Water Temperatures on Summertime Survival of Macrocystis Canopies. Hydrobiologia, 116-117, 419-424. http://dx.doi.org/10.1007/BF00027713

[38] Hernández-Carmona, G., Robledo, D. and Serviere-Zaragoza, E. (2001) Effect of Nutrient Availability on Macrocystis pyrifera Recruitment and Survival near Its Southern Limit off Baja California. Botanica Marina, 44, 221-229. http://dx.doi.org/10.1515/BOT.2001.029 
Scientific Research Publishing (SCIRP) is one of the largest Open Access journal publishers. It is currently publishing more than 200 open access, online, peer-reviewed journals covering a wide range of academic disciplines. SCIRP serves the worldwide academic communities and contributes to the progress and application of science with its publication.

Other selected journals from SCIRP are listed as below. Submit your manuscript to us via either submit@scirp.org or Online Submission Portal.
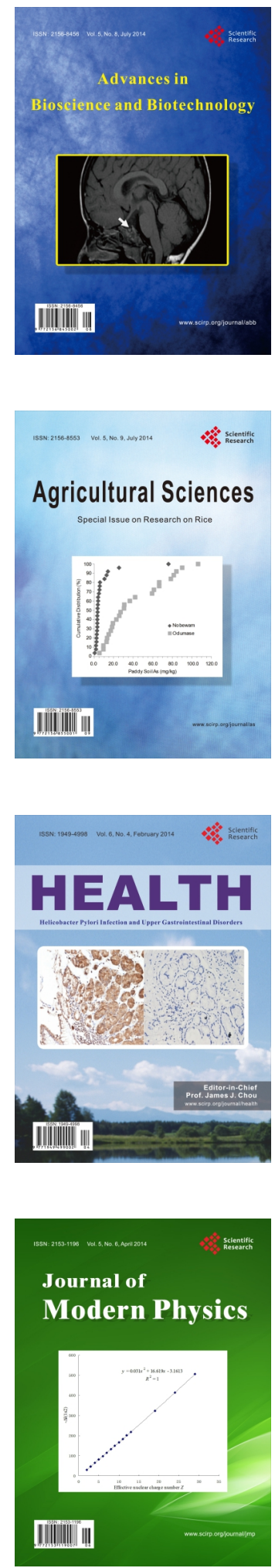
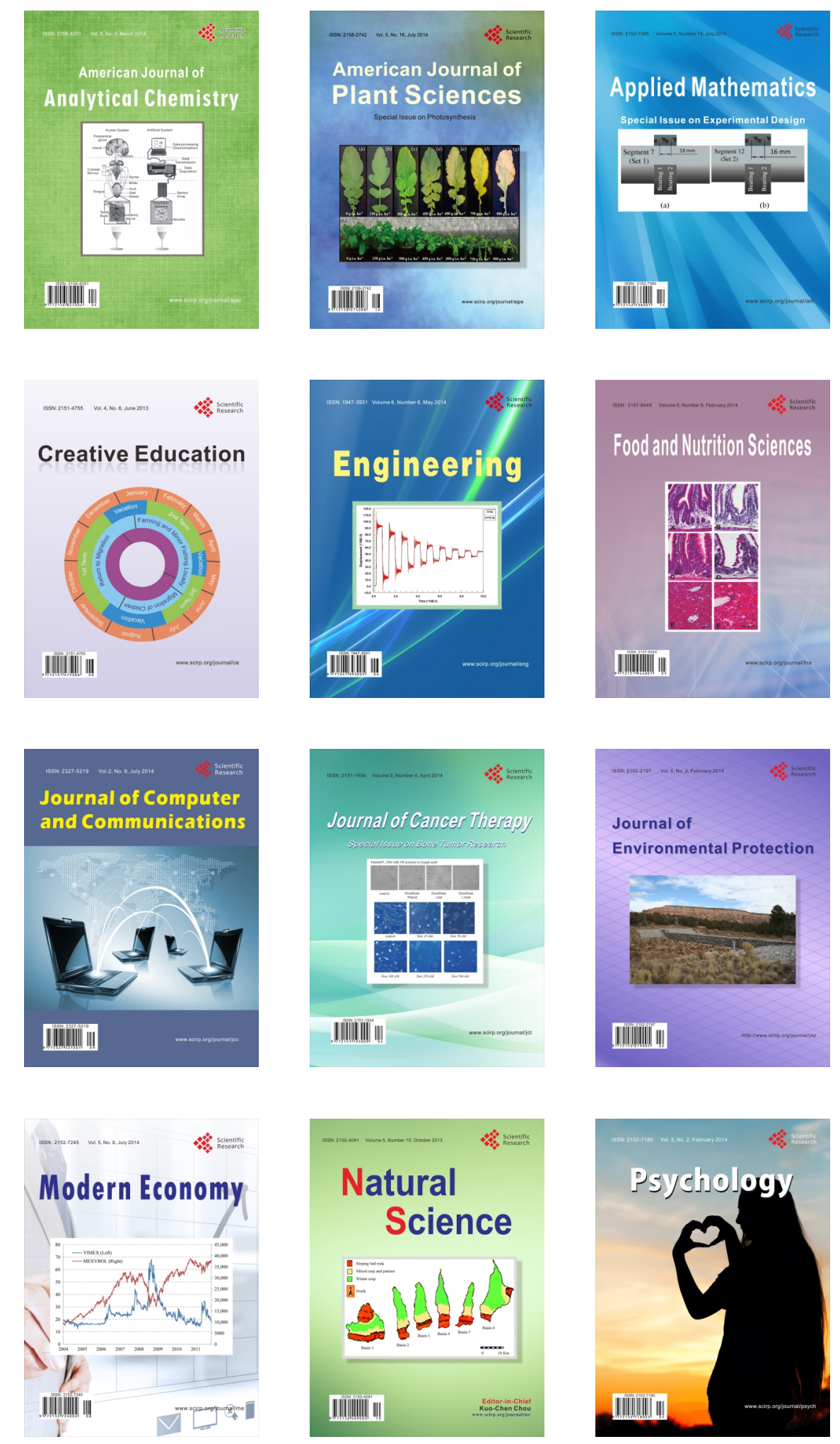